\title{
Application of the corridor management principle to the organization of the trans-Siberian railway
}

\author{
Daria A. Dinets ${ }^{1, *}$ \\ ${ }^{1}$ Irkutsk State Transport University, Irkutsk, Russia
}

\begin{abstract}
The article is focused on assessing the possibility of adapting the world experience of managing the transport corridor, including international ones, to the process of organizing and managing the Eastern railway polygon. Particular attention is paid to the analysis of the possibilities of implementing the corridor management principle on the basis of the Trans-Siberian railway in terms of competitive interactability with the railways of Europe, East and Central Asia in the framework of international transport construction projects. Conditions and prerequisites for achieving commercial return of transport construction projects and integration in terms of priority areas, types of cargo, types of rolling stock and the role of international transport integration in achieving the goals of socio-economic development of the regions have been revealed. It has been determined that the orientation to long-distance transport of bulk cargo hinders the implementation of the principle of corridor management on the Trans-Siberian Railway. It has also been proven that a vertically integrated structure with a network of unequal functional and territorial branches with fundamentally different goals hinders the possibility of ensuring non-discriminatory access to the railway transport infrastructure and specifically for intermodal transport operators. As a summary, the paper presents the key directions of improving the Trans-Siberian railway management and organization system to ensure competitiveness, obtain positive effects from the implementation of projects for organizing railway polygons, as well as effective integration into projects for the development of international transport corridors.
\end{abstract}

Keywords: transport economy, polygon technologies, international transport corridors

\section{Introduction}

Effective management of transport infrastructure means solving two main tasks in parallel: optimal resource allocation in terms of global value chains, as well as productivity growth that can be translated into all related sectors of the economy. To solve these problems, reformation pressure on the organization of transport operations and the principles of transport infrastructure management increases from time to time. Unfortunately, the reforms are mainly aimed at finding the best strategies for managing a vertical integrated holding in isolation from the tasks of horizontal integration [5].

With that, intermodal cooperation projects in transport industry are also being implemented in order to reduce the "economic distances" and to find ways to organize this interaction between the participants of the transport process, which will reduce the loss of added value in the transfer of goods between them. The lack of competitive advantages in interconnected types of transport is also a prerequisite for the non-profitability of transport construction and integration projects, the mass involvement of players in exchange trading in the carrying and thoughput capacity of integrated carriers.
The transport labor productivity growth is theoretically multiplied in related industries, which creates prerequisites for state interference in large transport infrastructure projects. In fact, however, we believe that the optimization mechanisms laid down in the structural reform in the railway transport industry have a limited impact on the multiplier effect and the growth of multifactorial productivity in the economy as a whole due to the wrong priorities between ensuring production and labor intensity in the task of productivity growth.

\section{Problem Statement}

The main problem of the modern stage of the development of the Trans-Siberian railway of the Russian railways is the lack of competitiveness of its proposed transport construction projects due to the impossibility of achieving their payback against the background of the expansion of international transport corridors of the global West and East. Geographical location has ceased to play an important role in the organization of logistics on the continent, and, therefore, natural advantages do not allow achieving efficiency. At the same time, it is impossible to achieve positive results

* Corresponding author: dinets@irgups.ru 
by copying foreign models of transport development due to the huge differences in the principles of its organization and the achievement of commercial success.

\section{Research Questions}

The subject of this study is the social and economic relations that arise when applying the principle of corridor management to the organization of the involvement of the Trans-Siberian railway in the international transport corridors of Eurasia. To achieve the study goal, it is required to do the following interconnected tasks:

1. Critical analysis of the practices of applying the principle of corridor management by the example of European and Asian routes.

2. Identifying the conditions for the successful implementation of the best practices of transport corridor management to the activities of the Trans-Siberian railway.

\section{Purpose of the Study}

The main purpose of this study is to identify the conditions for successful implementation of foreign projects to the experience of managing international transport corridors involving the Trans-Siberian railway.

\section{Research methods}

The author used historical and systemic analysis methods, comparison and grouping methods, comparison methods, and dialectical methods of cognition.

\section{Findings}

It is believed that the degree of influence of the development of transport infrastructure on multifactor performance is higher when the railway network under study contains more "bottlenecks". In other words, the development of transport infrastructure can make various contributions to the rationality of value chains depending on the actual needs for the infrastructure complex development [15]. This position can be accepted in the context of road development, but in the case of the Trans-Siberian railway, the connectivity of the territories along the railway network can be provided only when there are no bottlenecks throughout the mainline.

In particular, if we compare the scheme of the Russian railways with the scheme of railway communication in Europe, North America or the planned scheme of railways within the framework of the CAREC project, it is obvious that horizontal connections prevail in the first case and there are a lot of circular routes in all other directions. Therefore, debottlenecking of the Trans-Siberian railway, especially the part of it that runs to the east of the Ural Mountains, is a single technological task, which will be projected into a united growth of production and efficiency across the entire railway network [4].
At the same time, it is believed that the organization of integrated logistics makes it possible to optimize value chains by reducing the transport component in the cost of traded goods and partly services. For example, in the European Union the optimization of logistics interaction and the application of the corridor management principle to the organization of deliveries on integrated logistics networks, according to experts, leads to a reduction in the prices of transported goods by 13-15\% [3].

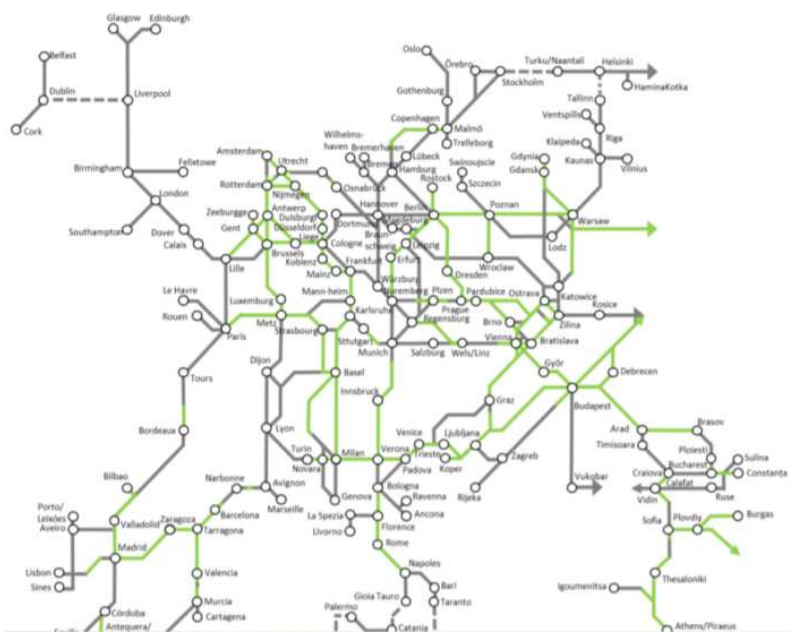

Figure 1. The diagram of the European railways [13]

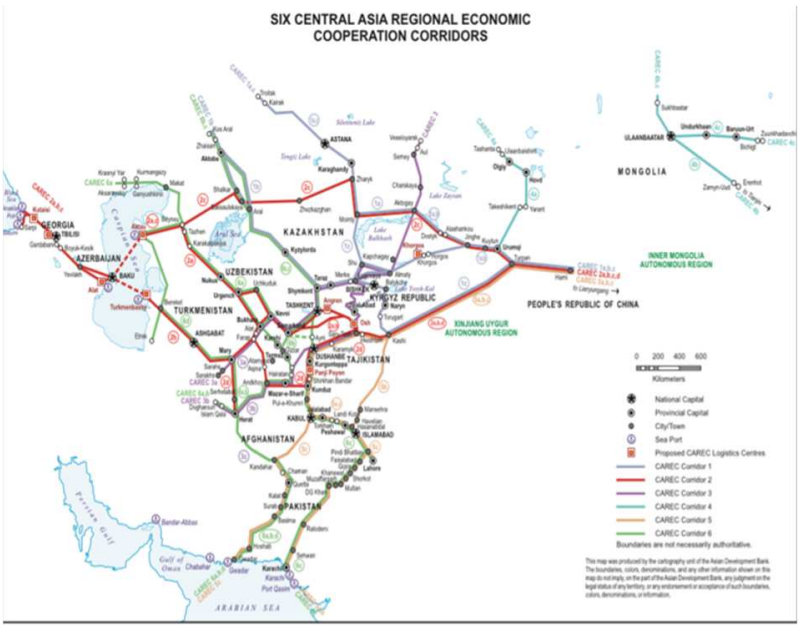

Figure 2. CAREC transport corridors [14]

We believe that such a high estimate can be obtained only if the transport service is optimized as a whole, and not only at the expense of the logistics organization in the "one stop principle". The availability of flexible infrastructure and high intermodality, stimulating the use of several modes of transport to build the most optimal route allow transport corridors to be effective at both long and short distances, when driving north-south and west-east without significant difference in the resulting positive economic impact. This is where we see the ability to have a positive impact on value chains and multifactor performance. And this, rather than the implementation of the technical process of management of the railway polygon, is where we see a kernel in the organization of transportation by the "corridor management" principle [6]. 
The matrix diagram of railways involves a matrix scheme of the value chain, while the vertically integrated holding company "Russian Railways" manages a horizontal integrated network of roads, and the formation of railway polygons is aimed at linking in a single process of vertically integrated functional branches.

If the national rail network is focused on increasing transportation range, it is not possible to compete on an equal footing in the problems of transport logistics and freight transshipment between different types of transport with matrix structures, and should never be the objective of structural reform in transport industry [7].

The inefficiency of the railway polygon management system is increasing due to the economically unreasonable outsourcing of logistics services in a united transport space in the process of forming an integrated transport service. Outsourcing is beneficial only if there is a positive economies of scale when transferring some of the fixed costs into variables or saving directly by a number of cost elements (most often, on labor costs and social contributions). The effectiveness of the latter measure is not proven if it is assessed not by the formal level of labor productivity, without taking into account the contribution of production and labor-intensive work. And the economy of scale, as it is known, acts both in growth and in reducing of indicators, as it is an objective economic phenomenon. In other words, if rail transport is competitive only for long-distance transportation of low-margin cargo, the expectation of a positive economies of scale from the outsourcing of logistics looks economically naive in the face of an increase in the cost of shipments and a decrease in average distance. At the same time, more than $70 \%$ of freight flows have been outsourced to logistics operators, and they carry out a near-complete cycle of cargo processing [8].

In this context, the rationality of the use of rolling stock is also an important problem: the number of suspended freight railcars is constantly increasing, station tracks possession rates are increasing [12], which invariably has a negative impact on the station speed and, of course, leads to a decrease in the competitiveness of railway transport.
Political, country and global risks also offer little room for optimism when forming a forecast of realistic development of the level of transport and logistics service on the Trans-Siberian railway with the involvement of logistics outsourcers. The transfer of goods to maritime transport is illustrated by the decline in the share of transport services in the total volume of service export. In the context of the coronavirus pandemic, the situation is somewhat changing, especially in recent times - from the moment of the permission of the transit of sanctioned goods on the railways of the EAEU. However, we believe that this is a temporary phenomenon, and there is no reason to expect that a mass transfer of cargo in containers from sea to rail. This is evidenced by the location geography of the main container terminals of the leaders of commodity platforms - most of it is located in places adjacent to the port capacities [1].

According to Professor H. Krampe's theory, all participants in the transport and logistics hub, which is the point of intermodality of the transport network, are economically equal and carry out their activities on the basis of their own benefit. At the same time, they should have non-discriminatory access to transport and logistics infrastructure [10].

In this context, this poses the question on the applicability of this model to Russian reality in achieving the goal of integrating the Trans-Siberian railway into international transport corridors. We suppose that the implementation of the "one stop principle" in the use of rail transport infrastructure is not achieved at this stage, even at the level of coordination of activity of the functional and territorial branches of the Russian Railways JSC, and not only at the level of united transport and logistics services in international transport corridors, even at the level of the EAEU. The situation is aggravated by the life cycle stage of the main part of objects of the infrastructure complex of the TransSiberian railway. In the context of systematic noncompliance with stop-hour plans, it is difficult to imagine the possibility of additional economy of scale from the growth of the service's competitiveness [9].

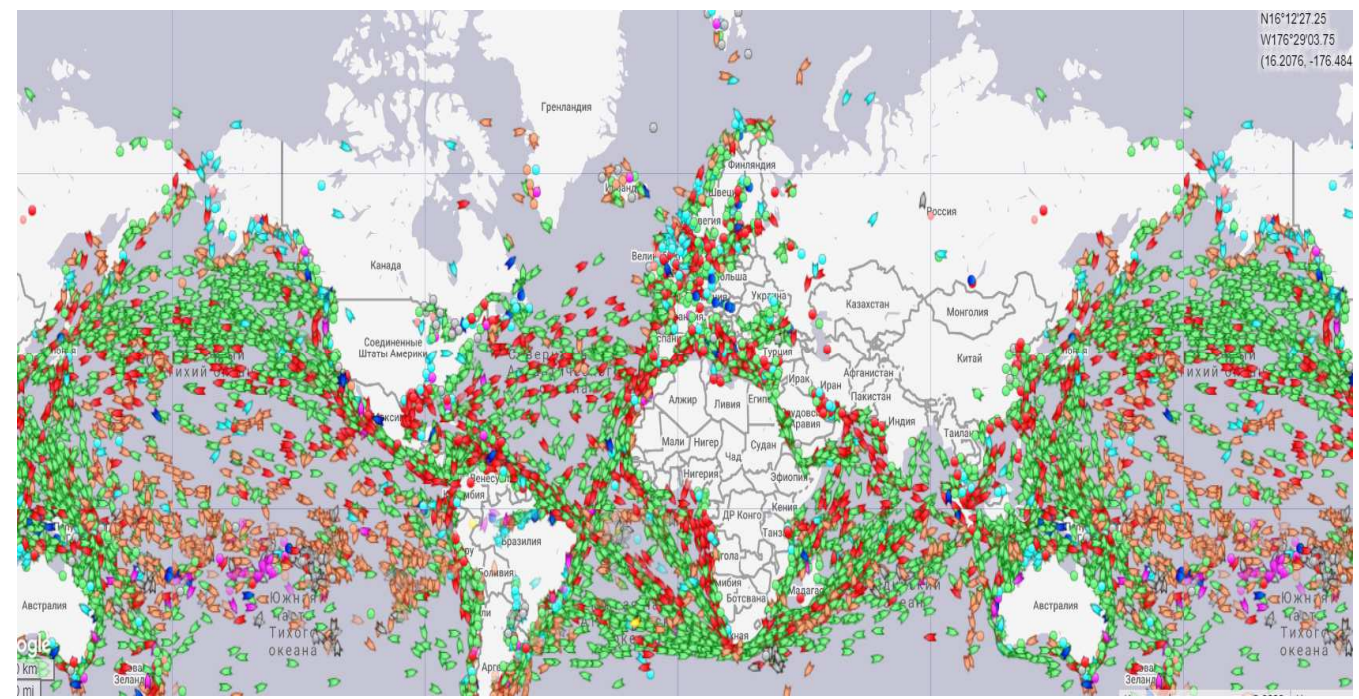

Figure 3. Sea ships traffic map [11] 
If we pay attention to the map of the movement of sea cargoes, we can draw an unequivocal conclusion about the irrationality of the existing service and logistics strategy of involving the Trans-Siberian railway in international transport corridors. Directions for the use of railway transport infrastructure and the use of transport infrastructure of seaports providing transit will not allow achieving the required synergies from transport integration projects. Comparison of the data presented with data on the structure of cargo turnover allows us to draw the following conclusions about the prospects of the Trans-Siberian railway involvement in international transport corridors as an equal partner.

The railcar clearing systems and the relative autonomy of the regional polygon control center bypassing the Regional Center of Corporate Management, operating by the rolling stock sidings, reserves of sidings for non-public use for private rolling stock.

\section{Conclusion}

The key findings that allow achieving this study goal are presented in Table 1.

Table 1. Main directions for improving the efficiency of implementing the corridor management principle to the TransSiberian railway

\begin{tabular}{|l|l|l|}
\hline \multicolumn{1}{|c|}{$\begin{array}{c}\text { Subject of } \\
\text { management }\end{array}$} & Current state & \multicolumn{1}{c|}{ Target model } \\
\hline $\begin{array}{l}\text { Management } \\
\text { and coordination }\end{array}$ & $\begin{array}{l}\text { Vertical } \\
\text { integration }\end{array}$ & $\begin{array}{l}\text { Horizontal and matrix } \\
\text { structures }\end{array}$ \\
\hline Bottlenecks & $\begin{array}{l}\text { without } \\
\text { reference to the } \\
\text { transport } \\
\text { corridor }\end{array}$ & $\begin{array}{l}\text { Impact on the } \\
\text { throughput and carrying } \\
\text { capacity of the entire } \\
\text { transport corridor }\end{array}$ \\
\hline $\begin{array}{l}\text { Performance } \\
\text { management }\end{array}$ & Production & Labour intensity \\
\hline activity & $\begin{array}{l}\text { Focusing on } \\
\text { range and } \\
\text { large-scale } \\
\text { involvement }\end{array}$ & Focus on intermodality \\
\hline $\begin{array}{l}\text { Suspended } \\
\text { railcars }\end{array}$ & $\begin{array}{l}\text { Reduction of } \\
\text { the service } \\
\text { speed }\end{array}$ & $\begin{array}{l}\text { There should be a } \\
\text { system of clearing of } \\
\text { one's own cars and stock } \\
\text { trading the possibility of } \\
\text { possessing tracks of } \\
\text { non-public use }\end{array}$ \\
\hline $\begin{array}{l}\text { An } \\
\text { infrastructure } \\
\text { lifecycle stage }\end{array}$ & $\begin{array}{l}\text { Systematic } \\
\text { the stop-hour } \\
\text { plan }\end{array}$ & $\begin{array}{l}\text { Changing the } \\
\text { technological process in } \\
\text { the transition to a matrix } \\
\text { system of management } \\
\text { and construction of third } \\
\text { tracks on the heavy- } \\
\text { traffic areas of the } \\
\text { eastern part of the } \\
\text { Trans-Siberian railway } \\
\text { and the Baikal-Amur } \\
\text { Railway }\end{array}$ \\
\hline
\end{tabular}

\section{Acknowledgments}

The work was carried out using the funds of the State task for the implementation of the project "Improving the mechanisms of interaction between the polygon structures and regional corporate governance centers by the example of the Eastern Railway polygon of the Russian Railways".

\section{References}

1. Financial settlements. Annual reports of JSC "UTLC ERA" (2019). Retrieved from: https://www.utlc.com/events/

2. B. Barisitz, A. Radzyner. The New Silk Road. Part II: A stocktaking and economic assessment. (2017). Retrieved from: https://www.wu.ac.at/fileadmin/wu/ d/cc/cee/1_Startseite/Barisitz_feei_4_17_OF.pdf

3. I. Bond. The EU, the Eurasian Economic Union and One Belt, One Road. Can they work together? (2017). Retrieved from: https://www.cer.eu/sites/ default/files/pb_eurasian_IB_16.3.17_0.pdf

4. B. Cosentino, D. Dunmore, S. Ellis, A. Pretti, D. Ranghetti, C. Routaboul, M. Garratt, A. Teodoro. Research for TRAN Committee: The new Silk Route - opportunities and challenges for EU transport (2018). Retrieved from: https://www.europarl. europa.eu/RegData/etudes/STUD/2018/585907/IPO L_STU(2018)585907_EN.pdf

5. D.A. Dinets, A.G. Dzhavrsuan. International transport corridors and transborder movement of fictitious capital. A. MATEC Web of Conf., 03013 (2018). DOI: 10.1051/matecconf/201823903013

6. D.A. Dinets, M.V. Konotopov. Transregionalism and fictive capital. E3S Web of Conf. Innov. Technol. in Environ. Sci. and Ed., 04033 (2019). DOI: $10.1051 / \mathrm{e} 3$ sconf/201913504033

7. Sixth report on monitoring development of the rail market pursuant to Article 15(4) of Directive 2012/34/EU of the European Parliament and of the Council. Europarlament reports (2012). Retrieved from:

https://ec.europa.eu/transport/sites/transport/files/sta ff_working_document_-6th_rmms_report.pdf

8. International trade of EU, the euro area and the Member States by SITC product group. Eurostat (2020). Retrieved from: www.eurasiancommission.org

9. I.D. Grachev, M.M. Sharapov. Evaluating the transition to gas engine fuel for the Western Europe - China international transit corridor (2016) Retrieved from: https://www.elibrary.ru/item.asp?id=25314488

10. L. Grob, N. Craven. Analysis of Regional Differences in Global Rail Projects by Cost, Length and Project stag (2017). Retrieved from: https://uic.org/IMG/pdf/analysis_of_global_rail_infr astructure_investment.pdf

11. Global ship tracking intelligence. Marine live map (2020). Retrieved from: https://www.marinetraffic. com/en/ais/home/centerx:-12.0/centery:25.0/zoom:4

12. Strategic Transport Infrastructure Needs to 2030. OECD reports. Transport (2019). Retrieved from: https://read.oecd-ilibrary.org/economics/strategic- 
transport-infrastructure-needs-to-

2030_9789264114425-en

13. Signaling systems. Open Railway Map (2020). Retrieved from: https://www.openrailwaymap.org/ ?lang=ru\&lat $=48.019324184801185 \&$ lon $=14.78759$ $765625 \&$ zoom $=5 \&$ style $=$ signals

14. C. Secchi, S. Riela. Infrastructure for growth: how to finance, develop and protect it (2019). Retrieved from: https://www.ispionline.it/sites/default/files/ media/pdf/infrastructure_study.pdf

15. A. Tunnicliffe. Horizon 2020: a look at the EU's flagship rail projects (2020). Retrieved from: https://www.railway-technology.com/features/ horizon-2020-rail-projects/ 